\title{
IMPROVEMENT OF BLASTING OPERATION IN SUKARI SURFACE MINE
}

\author{
*Ramy A. Mosa ${ }^{1}$, Saeed S. Abdel-Hafiz ${ }^{2}$ and Mohamad. A. Yassin ${ }^{3}$ \\ ${ }^{1}$ Mining and Petroleum Dept., Faculty of Eng., Al-Azhar University, Qena, Egypt \\ ${ }^{2}$ Mining and Metal. Dept, Faculty of Eng., Assiut University, Assiut, Egypt \\ ${ }^{3}$ Mining and Petroleum Dept., Faculty of Eng., Al-Azhar University, Cairo, Egypt \\ *Corresponding author E-mail: e.rm@azhar.edu.eg
}

\begin{abstract}
Detailed blasting data had been collected from Sukari gold mine.These data were arranged and computerized to feed a simulation software.DNA i-Blast is one of the powerful software for simulating, analyzing, and prediction the blasting products.As fragmentation is the main effective parameter of blasting, so we focused on the fragmentation size distribution according to RosinRammeler equation.To assure the output size, an analysis for real fragment images was carried out and it gives almost the same results. According to simulation results, two improvements in blast-hole design are suggested. First suggestion is using air-deck of $25 \%$ of the charge column, and the second is using denser explosive. One of these suggestions or both of them can be applied and gives obviously reduction in the particle sizes.
\end{abstract}

KEY WORDS: Sukari Gold Mine; SGM, Blasting, Fragmentation, DNA I-Blast, Air-Deck

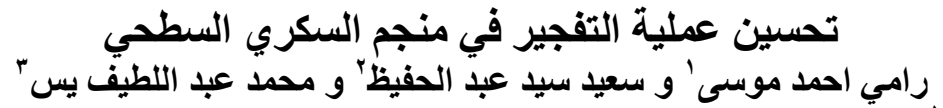

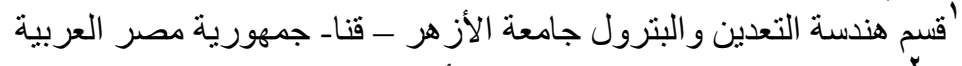

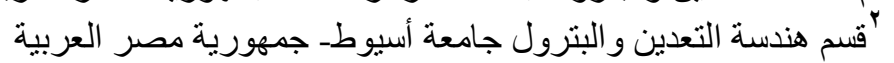

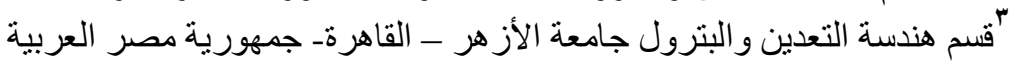

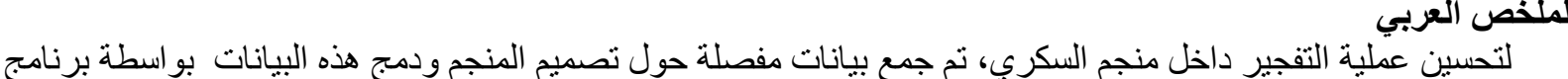

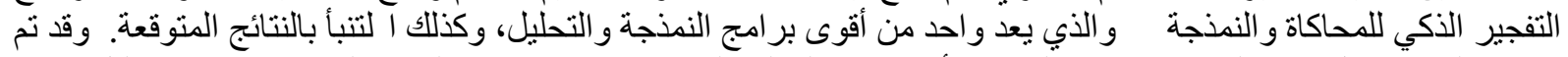

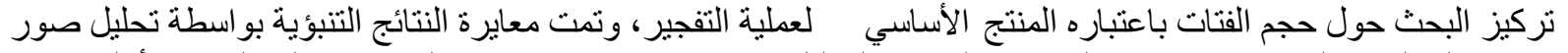

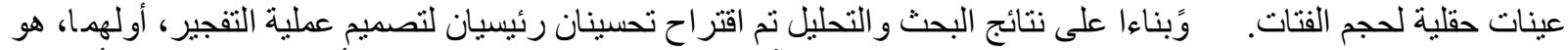

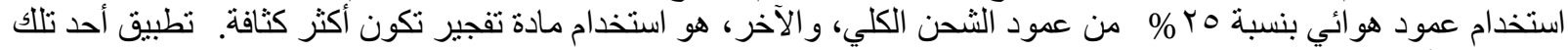

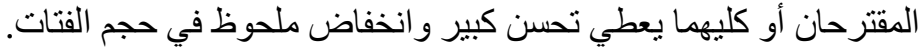

الكلمات الافتتاحية : منجم السكري ، سنتامين مصر ،تفجير ـ فتات صخري ، برنامج محاكاة ، طبقة هو ائية

\begin{tabular}{|c|c|c|c|}
\hline \multicolumn{4}{|c|}{ NOMENCLATURE } \\
\hline SGM & Sukari gold mine & PF & Powder factor \\
\hline ANFO & Ammonium nitrate/fuel oil & AEL & Supplier and manufacturer of Explosives \\
\hline C & Compressive strength, Mpa & $\mathbf{C a}$ & Measured compressive strength, Mpa \\
\hline $\mathbf{R}(\mathbf{x})$ & Proportion of the material passing through the opening & $\mathbf{x}$ & Screen size, cm \\
\hline $\mathbf{X c}$ & Characteristic size, $\mathrm{cm}$ & $\mathbf{n}$ & Index of uniformity \\
\hline B & Burden, m & d & Charge diameter, mm \\
\hline W & Standard deviation of drilling accuracy, $\mathbf{m}$ & $\mathbf{L}$ & Charge length, $\mathrm{m}$ \\
\hline $\mathbf{H}$ & Bench height, m & $\mathbf{R}$ & Spacing/Burden \\
\hline
\end{tabular}




\section{INTRODUCTION}

One of the most important gold mines in Egypt is Sukari gold mine (SGM) sponsored by Centamin Company. Sukari tenement area locates at the Eastern Desert of Egypt. The current pit design is considered as Super Pit; only two pits achieved such big design before. The age of the pit is planned to be 30 years started from 2009. The blast pattern produce an average of 150,000 ton/day of blasted rock. The mine consumes 37 tons of ANFO per day, with PF of $0.68 \mathrm{~kg} / \mathrm{m}^{3}$ to break the quartz barren rocks [1].

Blasting process represents great importance in the cost of further mining processes specially comminution process [2]. Blasting is one of the main operations in open pit mines, affecting the total revenue of the mine to a large extent [3]. It is generally necessary to break large volumes of rock, especially if the rock is medium to high strength. An indication of the importance of blasting is that more than 1 billion $\mathrm{kg}$ of explosives are used annually in Australia and 3 billion $\mathrm{kg}$ in the United States for rock breakage, more than $85 \%$ of which is used in the mining industry. Explosives are the first choice of mining engineers for primary fragmentation and will continue to be so for the foreseeable future [4].

The primary objective of rock blasting is to attain a successful fragmentation. The classification and size distribution of muckpile are the critical components of managing any blasting operation. The fragmentation affects all downstream operations including loading, hauling and crushing; so it can be used to minimize these costs [2] [5]. In order to control and optimize the process effectively, it is essential to adopt a rapid and reliable technique for assessing the degree of fragmentation. This is also important from the design point of view where various different types of explosives and blast designs can be quickly and efficiently analyzed. Reliable evaluation of fragmentation is a critical mining issue and quick and accurate measurements of size distribution are essential to manage fragmented rock. It can be used to optimize all blasting parameters to reduce overall costs [5] [6] [7].

\section{BLASTING DATA AND METHOD}

\subsection{Geology of Sukari area}

The Sukari orebody is a variably altered granodioritic intrusion hosted in a complex mafic and intermediate volcano-sedimentary package. The granodiorite contains variable sericite, silica, kaolinite, albite, hematite and ankerite alteration assemblages. The texture of the rock appears porphyritic in areas and equigranular in others due to the effects of the overprinting alteration; hence the orebody has been termed the Sukari Porphyry [1] [8]. The porphyry contains $99 \%$ of the known gold mineralisation which is hosted in through-going shears and veins. The host sequence contains less than $1 \%$ of the bulk gold reserves, hosted in shears and along hostporphyry contact zones. The shears and veins trend north-south and dip $45^{\circ}$ to $60^{\circ}$ to the east and are continuous throughout the Amun Zone. The porphyry outcrop is expressed as a $2500 \mathrm{~m}$ long ridge rising to $350 \mathrm{~m}$ above the local wadi level. The very steep topography causes very difficult access for drilling [1]. The mine property is divided into nine zones, six zones for open pit mine and three for underground mine. All these zones are namely in Fig. 1, but Amun zone reaches its end at 2014. Exploration is continued in Horus zone through the underground mine [1]. 


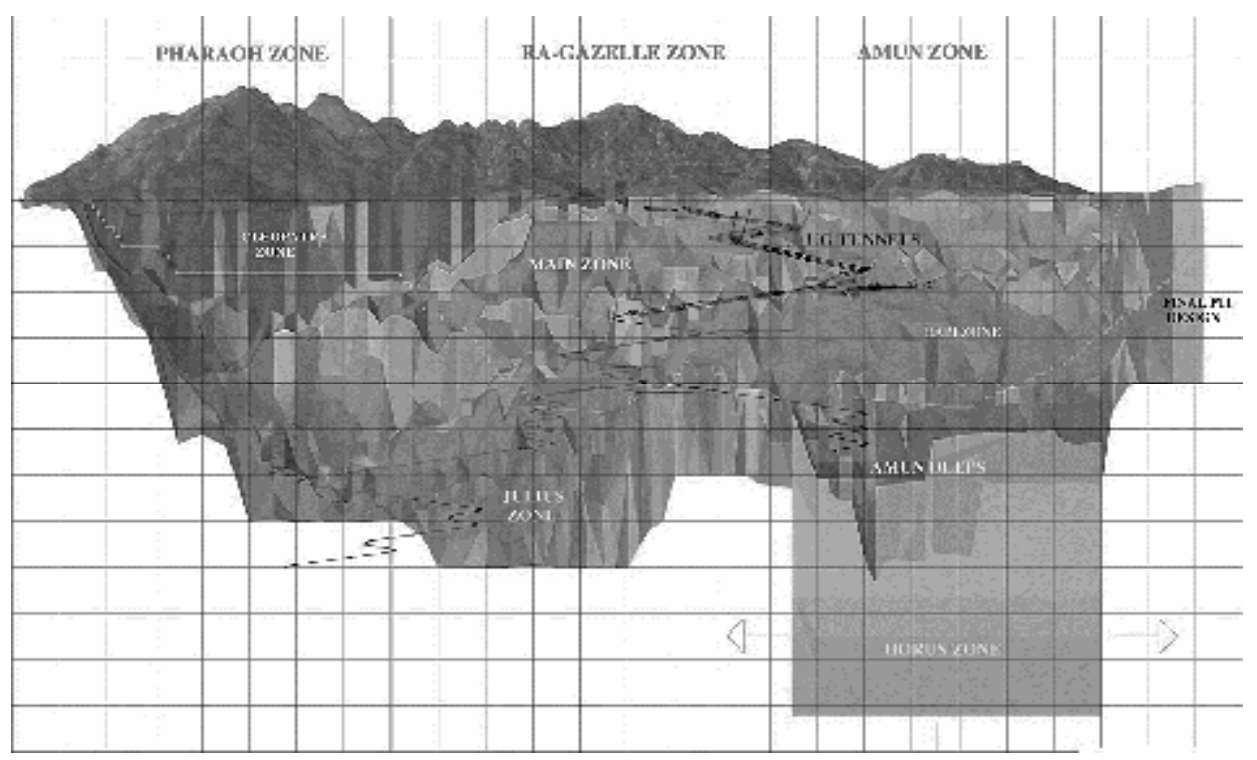

Fig. 1. Sukari gold mine zones

\subsection{Blasting current state in SGM}

A data of 30 shot fire of blasting operation supplied by AEL Company for the benefit of SGM had collected along the month of December 2015. These data were arrange as shown in Table 1 to feed the simulation software program.

Table 1: Blasting data of SGM in Dec. 2015

\begin{tabular}{|c|l|c|c|}
\cline { 2 - 4 } \multicolumn{1}{c|}{} & Parameter & Value & Unit \\
\hline \multirow{4}{*}{ PATTERN } & Burden & 4.8 & $\mathrm{~m}$ \\
\cline { 2 - 4 } & Spacing & 5.3 & $\mathrm{~m}$ \\
\hline \multirow{4}{*}{ DRILLING } & Hole Depth & 21.3 & $\mathrm{~m}$ \\
\cline { 2 - 4 } & Bench Height & 20 & $\mathrm{~m}$ \\
\cline { 2 - 4 } & Sub-Drill & 1.3 & $\mathrm{~m}$ \\
\cline { 2 - 4 } & Hole Diameter & 165 & $\mathrm{~mm}$ \\
\hline \multirow{4}{*}{ CHARGE } & Column Length & 4.8 & $\mathrm{~m}$ \\
\cline { 2 - 4 } & Stemming Length & 0.854 & $\mathrm{~g} / \mathrm{m}^{3}$ \\
\cline { 2 - 4 } & PF & emulsion & - \\
\cline { 2 - 4 } & Type & 4.5 & $\mathrm{per}$ \\
\hline
\end{tabular}

SGM had been gathered data for rock unconfined compressive strength periodically for the project feasibility stage of the operation. These data indicate that UCS of Sukari rocks varies from $2 \mathrm{MPa}$ for black shale to 200MPa for hard fresh porphyry). Hence the mean value which is around $100 \mathrm{MPa}$ can be used for software feeding. Although this study has used $100 \mathrm{MPa}$ as the base case, but the actual UCS of rocks is very important in many parameters critical to estimation of drilling and blasting resources and costs. Also blasting pattern, explosive type, and penetration rate are very sensitive to rock strength.

\subsection{Software feeding}

DNA i-Blast feeding involved three stages; namely rock mass to define formation characteristics, explosives to define the type and properties of explosive material, and loading to define the hole charging shape [9]. Then the pattern design was inserting to the program using $\mathrm{x}, \mathrm{y}, \mathrm{z}$ coordinates. After that, the holes is charged by one of predefined charge and connected by timing wires to 
achieve delay requirements according to the original field design. Fig. 2 shows an example of final pattern on the program in $2 \mathrm{D}$ and $3 \mathrm{D}$ view.

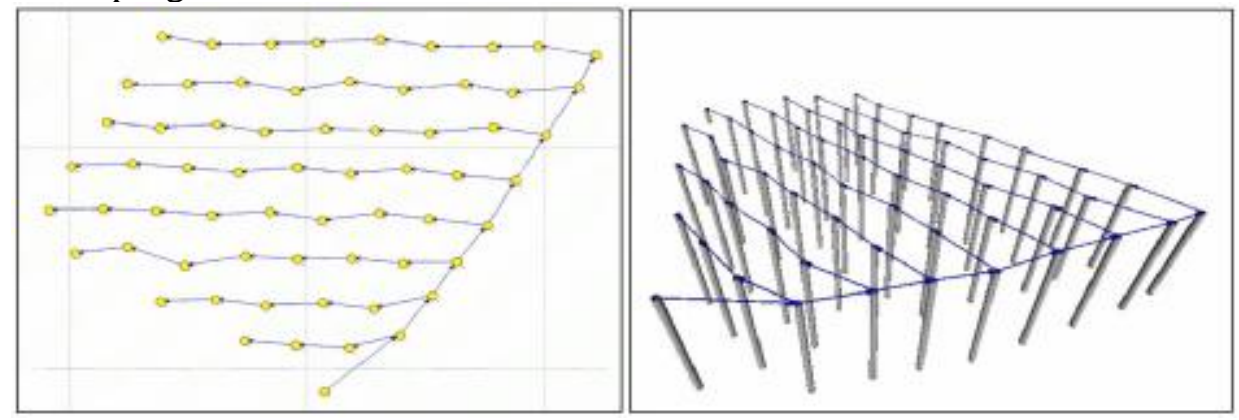

Fig. 2. Complete charged pattern in $2 D$ and $3 D$ view

The analysis process was achieved in the program by merging all data via statistical methods to obtain many probability trees. It is automatically choose the best analytical method according to provided data to produce the highest accuracy. Simulation and analysis processes to obtain the fragmentation size distribution from one-hole impact is achived by using Rosin-Rammiler [5] [10] Eq. 2 by the program.

$$
R(x)=1-e^{-\left(\frac{x}{x c}\right)^{n}}
$$

Eq. 2

Where $n$ is varies from $0.8-2.0$ and can be calculated from:

$$
n=\left\{2.2-14 \times \frac{B}{d}\right\} \times\left(1-\frac{W}{B}\right) \times \frac{L}{H} \times\left\{1+\frac{(R-1)}{2}\right\}^{0.5} \quad \boldsymbol{E q} .3
$$

\subsection{Calibrate the simulation based on field experiments:}

To assure the output fragmentations size from the previous simulation, field analyzes for real fragments should be achieved to check if it gives the same results. There are two main classes for size distribution measurement several methods. First is direct methods by sieving or screening analysis. It is accurate method but for production blasting, it is costly, time-consuming and inconvenient. Hence, another indirect methods that involve observational, empirical or digital methods had been developed. Using one of indirect methods by fragment image analysis technique provides rapid and accurate blast fragmentation distribution assessment possible [11] [12] [13]. I-Blast have an option based on 2D image processing for performing size distribution analysis of the blasted rock blocks. Fig. 3 shows the stages of this processing.

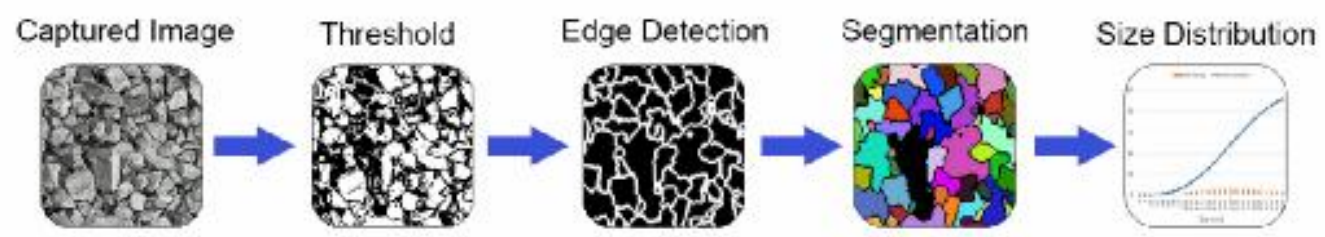

Fig. 3. Flow chart of fragment image analysis process

\section{RESULTS AND DISCUSSION}

\subsection{Blast hole simulation}

Fragmentation size distribution which shown in Fig. 4 is shown that the maximum size of fragmentation can reaches to $471 \mathrm{~mm}$ with $1.6 \%$ of whole fragmentation volume. The minimum size with significant portion is equal to $114 \mathrm{~mm}$. The majority of size is concentrated between ( $260 \mathrm{~mm}-$ $292 \mathrm{~mm})$. 


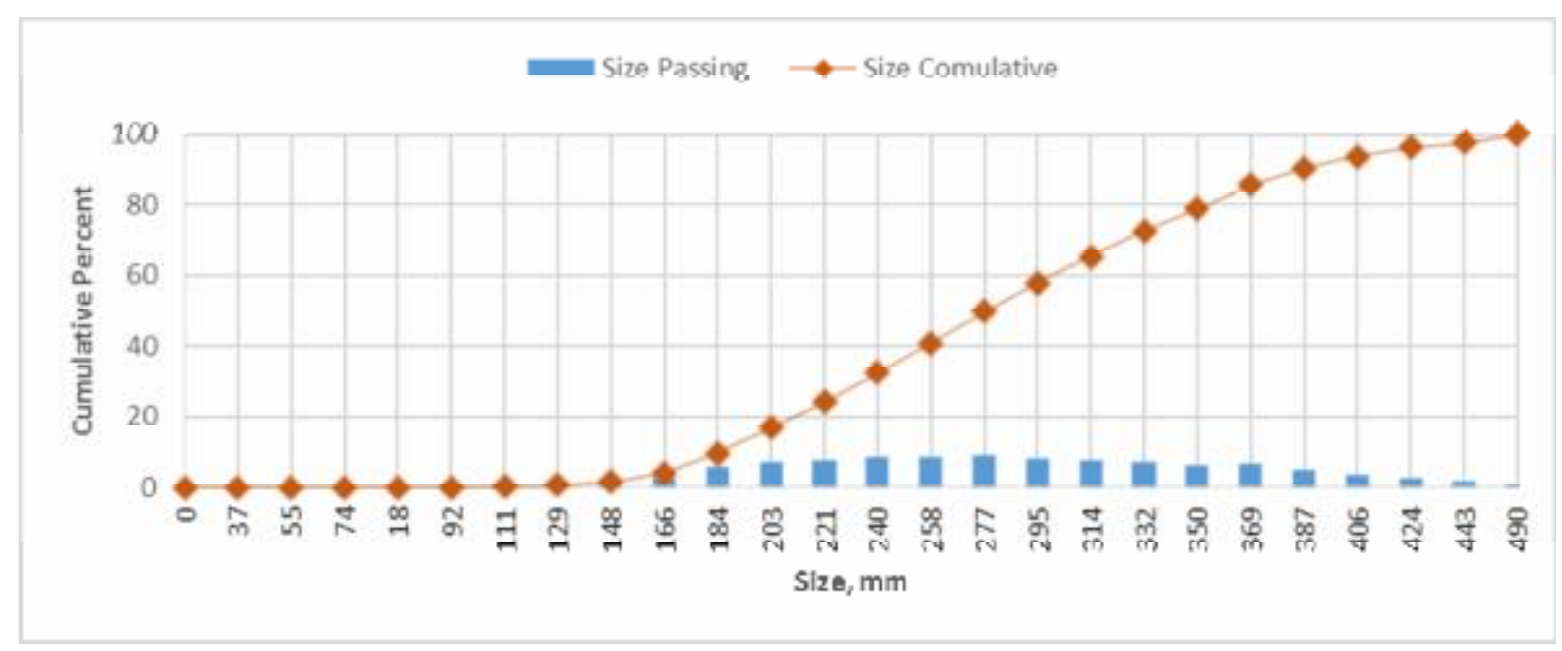

Fig. 4. Fragmentation size distribution

Size Cumulative curve shows that $50 \%$ of whole fragmentation volume is obtained at size $255 \mathrm{~mm}$. The mean fragmentation size is approximately $236 \mathrm{~mm}$ Table 2 shows detailed results for statistical analysis of this data.

Table 2: Statistical description of size distribution

\begin{tabular}{|c|c||c|c|}
\hline Maximum & $490 \mathrm{~mm}$ & Percentile 25 & $171 \mathrm{~mm}$ \\
\hline Mean & $266 \mathrm{~mm}$ & Percentile 50 & $268 \mathrm{~mm}$ \\
\hline Standard Deviation & $127 \mathrm{~mm}$ & Percentile 90 & $422 \mathrm{~mm}$ \\
\hline
\end{tabular}

\subsection{Image analysis process}

Fig. 5 shows the Cumulative size distribution of fragmentations detected by image processing technique in comparing to the cumulative size distribution in Fig. 4, which obtained from blasting simulation. It is very clear that the two curves is almost the same with little reduction of about $5 \mathrm{~cm}$ in image analysis curve. This difference is due to the accuracy of image processing is limited to somewhat large fragments which is easily detected digitally. In addition, the maximum size in blasting simulation is about $47 \mathrm{~cm}$ while for image simulation is $48.6 \mathrm{~cm}$. Hence, the simulation may be acceptable.

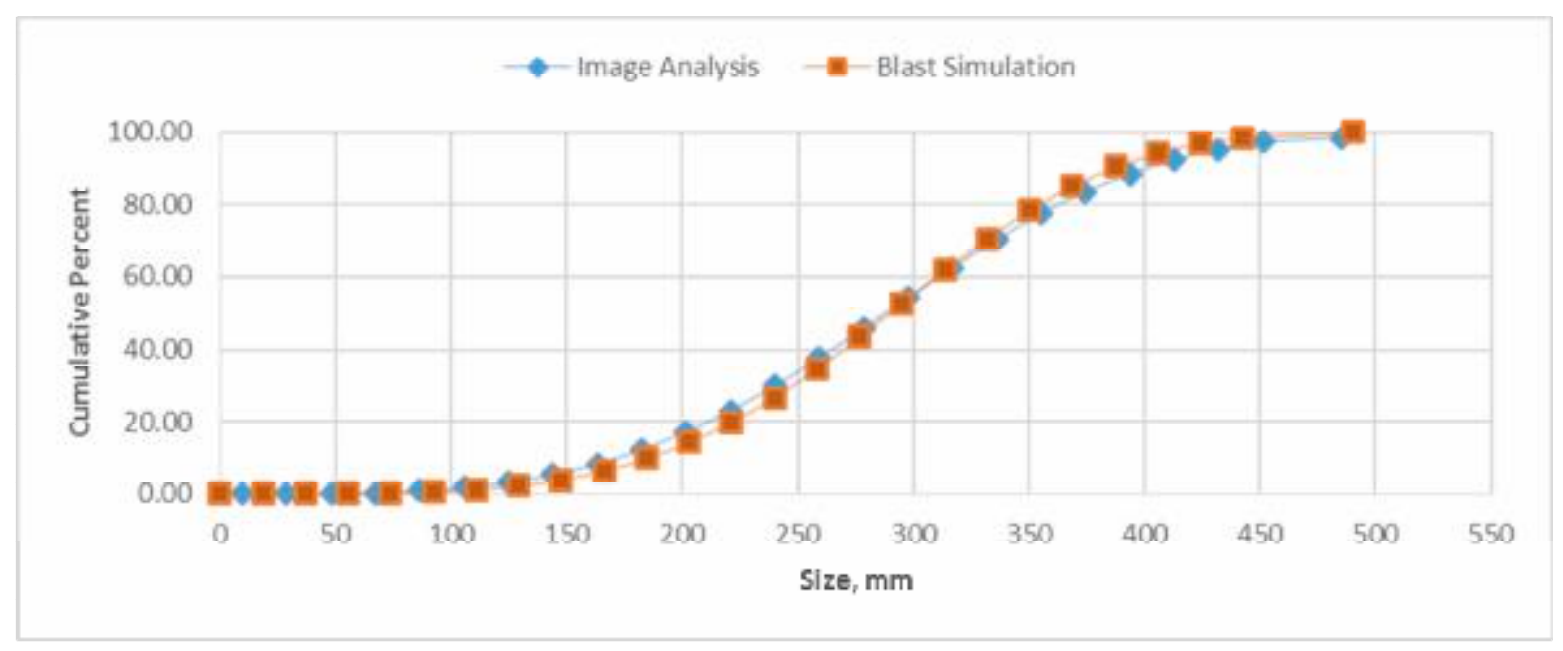

Fig. 5. Fragmentations cumulative size distribution obtained from image analysis comparing to distribution obtained form blasting simulation 


\section{IMPROVEMENT SUGGESTIONS}

In blasting field, conducting field experiments is very difficult because of the high cost and strict security procedures. After calibrating the simulation results and ensuring their proximity to the field results the great importances of the simulation model is appeared. Where it can be confirmed with a degree of confidence the expected results of the blasting. Consequently, there are two suggestions to improve blasting results as follows:

\subsection{Using Air-deck}

Experience within the UK has confirmed that air-deck volumes of $25-30 \%$ can be employed in all rock types. Fig. 6 shows notable reduction in maximum fragmentation size from $471 \mathrm{~mm}$ to $432 \mathrm{~mm}$.

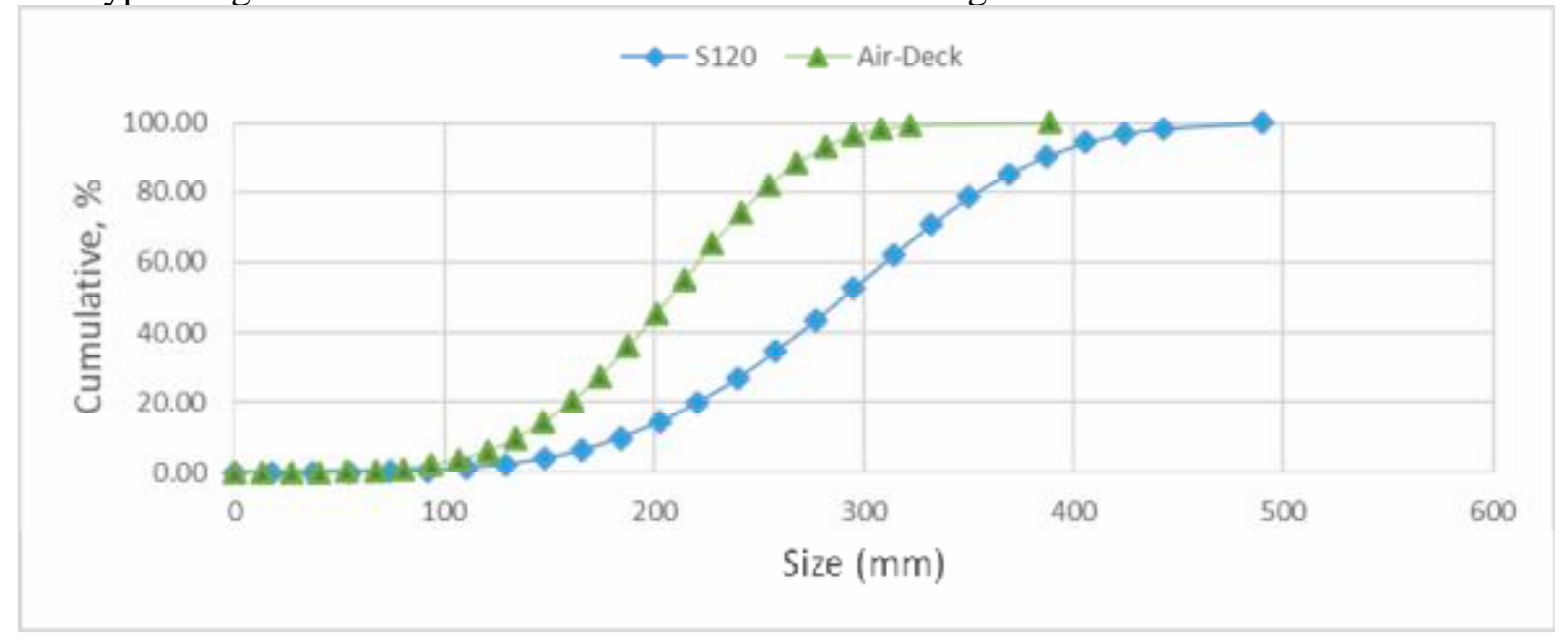

Fig. 6. Blasting current state in comparing to using air deck

With this method, $25 \%$ of whole fragmentation volume is obtained at size $124 \mathrm{~mm}$. The mean fragmentation size is approximately $195 \mathrm{~mm}$. Table 3 shows in detail the comparison between results in two cases as statistical description.

Table 3: Blasting current state in comparing to using air deck

\begin{tabular}{|c|c|c|}
\hline \multirow{2}{*}{ DATUM } & \multicolumn{2}{|c|}{ CHARGE } \\
\cline { 2 - 3 } & S120 & Air-Deck \\
\hline Maximum & $490 \mathrm{~mm}$ & $389 \mathrm{~mm}$ \\
\hline Mean & $266 \mathrm{~mm}$ & $195 \mathrm{~mm}$ \\
\hline Standard Deviation & $127 \mathrm{~mm}$ & $95 \mathrm{~mm}$ \\
\hline Percentile 25 & $171 \mathrm{~mm}$ & $124 \mathrm{~mm}$ \\
\hline Percentile 50 & $268 \mathrm{~mm}$ & $194 \mathrm{~mm}$ \\
\hline Percentile 90 & $422 \mathrm{~mm}$ & $307 \mathrm{~mm}$ \\
\hline
\end{tabular}

\subsection{Using denser explosive}

Using higher density explosive type, e.g. S135 from AEL Company can significantly improve blasting results. Fig. 7 shows notable reduction in maximum fragmentation size from $471 \mathrm{~mm}$ to $407 \mathrm{~mm}$. It is also clear that this method surpasses the air-deck method. 


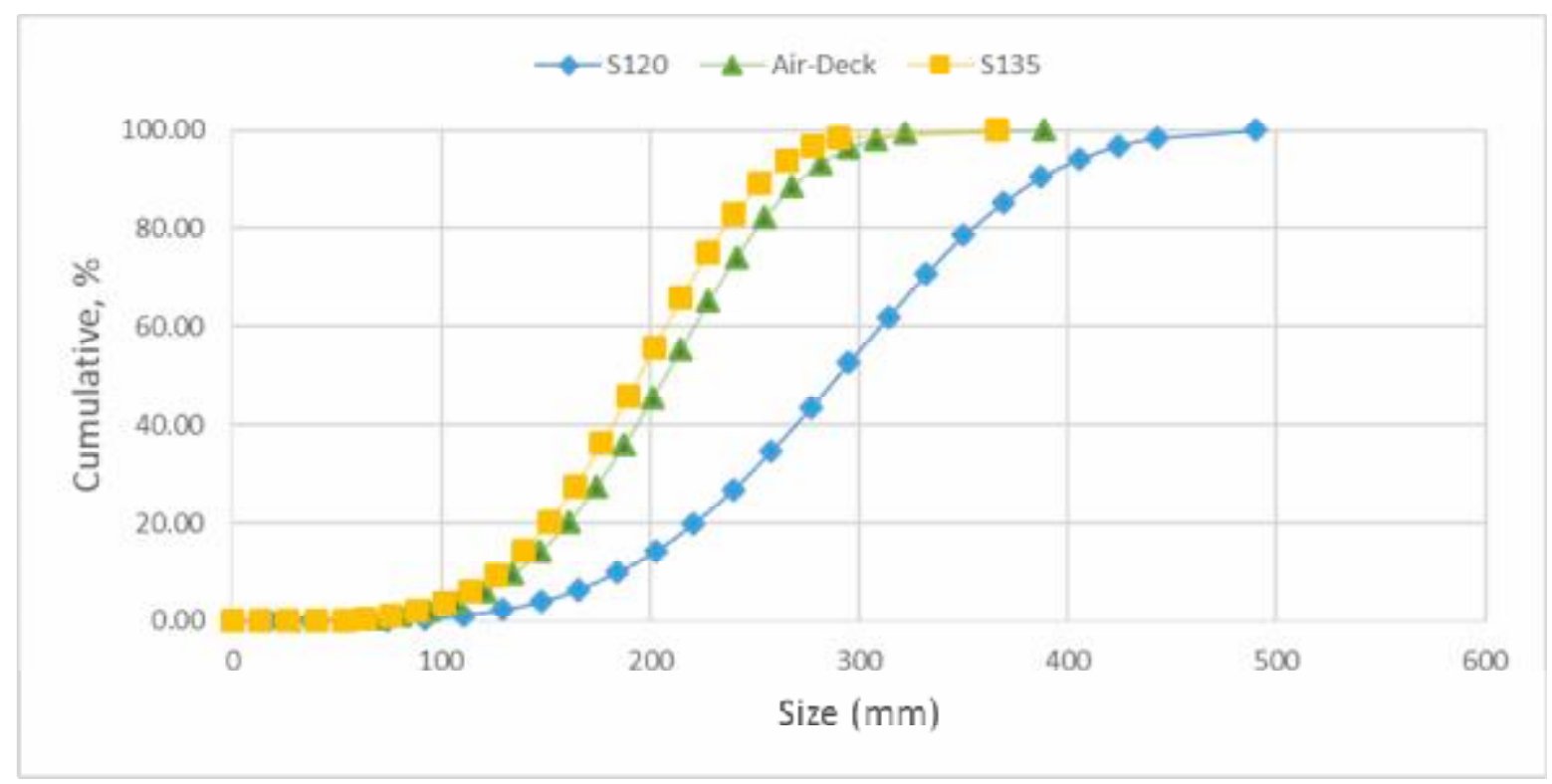

Fig. 7. Blasting current state in comparing to using air deck and denser explosive

With this method, $25 \%$ of whole fragmentation volume is obtained at size $114 \mathrm{~mm}$ which is about equal to the crusher set $(113 \mathrm{~mm})$. The mean fragmentation size is approximately $204 \mathrm{~mm}$. Table 4 shows in detail the comparison between results in three cases as statistical description.

Table 4: Blasting current state in comparing to using air deck and denser explosive

\begin{tabular}{|c|c|c|c|}
\hline \multirow{2}{*}{ DATUM } & \multicolumn{3}{|c|}{ CHARGE } \\
\cline { 2 - 4 } & $\mathbf{S 1 2 0}$ & Air-Deck & S135 \\
\hline Maximum & $490 \mathrm{~mm}$ & $432 \mathrm{~mm}$ & $366 \mathrm{~mm}$ \\
\hline Mean & $266 \mathrm{~mm}$ & $195 \mathrm{~mm}$ & $178 \mathrm{~mm}$ \\
\hline Standard Deviation & $127 \mathrm{~mm}$ & $95 \mathrm{~mm}$ & $89 \mathrm{~mm}$ \\
\hline Percentile 25 & $171 \mathrm{~mm}$ & $124 \mathrm{~mm}$ & $114 \mathrm{~mm}$ \\
\hline Percentile 50 & $268 \mathrm{~mm}$ & $194 \mathrm{~mm}$ & $177 \mathrm{~mm}$ \\
\hline Percentile 90 & $422 \mathrm{~mm}$ & $307 \mathrm{~mm}$ & $278 \mathrm{~mm}$ \\
\hline
\end{tabular}

\section{CONCLUSION}

1) Using air deck technique reduces the average fragmentation size from $266 \mathrm{~mm}$ to $195 \mathrm{~mm}$ with the same amount of explosive.

2) Using denser explosive (namely S135 from AEL in this study) can reduces the average fragmentation sizes from $266 \mathrm{~mm}$ to $178 \mathrm{~mm}$ with the same amount of explosive.

3) In case of S135 explosive material, $25 \%$ of whole fragmentation products got in size $114 \mathrm{~mm}$ which approximately equals to the crusher set.

4) It expected that the combining of two improvement suggestions (i.e. air-deck and denser explosive) can provide better results.

5) In addition to the blasthole design and explosive type, the simulation model can be used to study many other parameters influencing the blasting process, as well as suggest many improvements. 


\section{REFERENCES}

1. Centamin (Accessed 2012) Sukari gold mine. Available at: http://www.centamin.com/production/sukari/overview

2. Kennedy, B. (1990) Surface Mining. Society for Mining,Metallurgy, and Exploration, Inc. SME, Colorado.

3. Gustafsson, R. (1973) Swedish Blasting Technique. SPI, Gothenburg, Sweden.

4. Rostami, J., Hambley, D. (2011) Rock Breaking Methods. In : SME mining engineering handbook 3rd edn. Society for Mining, Metallurgy, and Exploration, Inc. (SME), Newyork 417-459.

5. Hustrulid, W. (1999) Blasting Principles for Open Pit mining. A. A. Balkema, USA.

6. Bhandari, S. (1997) Engineering Rock Blasting Operations. A.A. BALKEMA, Brookfeild.

7. Sanchidrián, J. A., Singh, A. K. (2013) Measurement and Analysis of Blast Fragmentation. Taylor \& Francis Group, London.

8. Helmy, H. M., Kaindl, R., Fritz, H., Loizenbauer, J. (2004) The Sukari Gold Mine, Eastern Desert-Egypt: structural setting, mineralogy and fluid inclusion study. Mineralium Deposita 39(2), 495-511.

9. (Accessed 2015) I-Blast PRO. Available at: http://www.dna-blast.com/Blasting-DesignSimulation-Optimization/I-Blast_PRO.html

10. Kihlström, B., Langefors, U. (1963) The Modern Technique of Rock Blasting. Wiley, New York.

11. Kim, K. (2006) Blasting Design Using Fracture Toughness and Image Analysis of the Bench Face and Muckpile. MS Thesis, Virginia Polytechnic Institute and State University.

12. Zhang, Z., Yang, J., Ding, L., Zhao, Y. (2012) Estimation of coal particle size distribution by image segmentation. International Journal of Mining Science and Technology 22(5), 739-744.

13. Chimi-Chiadjeu, O., Hégarat-Mascle, S. L., Vannier, E., Taconet, O., Dusséaux, R. (2014) Automatic clod detection and boundary estimation from Digital Elevation Model images using different approaches. Catena 118(3), 73-83. 